\title{
Revitalizing Transport Rickshaw Into A Tourist Heritage Vehicle (Case Studies In Bandung, Indonesia)
}

\author{
Gema Arifrahara \\ Design Faculty \\ Universitas Komputer Indonesia \\ Bandung, Indonesia \\ gema.arifrahara@.email.unikom.ac.id
}

\begin{abstract}
Revitalizing alternative vehicle such as rickshaw tours that will invite travelling passengers to enjoy the beauty of the city. The method used is a survey which is a descriptive observation on point by doing the work. The research aims to change the concept of the pedicab which is currently a rickshaw tour to reminisce with touring the city. A number of 100-150 sheets of questionnaires were distributed followed by a return of only 94-123 sheet. Kuester is deployed on towing the pedicab and rickshaw to the customer. Government policies are still awaiting for the existence of a step in a realignment of the conventional vehicle and the rider into a pedicab vehicle tours. The pedicab is currently one of the vehicles that disturb the smooth pace of traffic. Breaking the rules against the current and dismissing it arbitrarily. This research will be able to be applied as a step that can be used by the City Government on the rickshaws so that it can function as tourist vehicles in the city. As for recommendations to the parties concerned, in particular the regulator so that the realignment of the role of the pedicab of commercial vehicles can be seen as an alternative tour within the city.
\end{abstract}

Keywords - Traditional transport, rickshaw, tour

\section{INTRODUCTION}

Revitalizing traditional vehicles became the vehicle tour is a move made to provide solutions to the problems currently perceived by urban communities. The vehicle is a rickshaw transport vehicles has become already a long time ago people used to travel in the city in close proximity. Its function in the tool of the human-powered commercial transport is never effective to be the mainstay of the city's vehicles daily. Modernization makes everything fast paced makes this vehicle getting unnoticed even today to be one of the issues that may interfere with the smooth running of traffic. Change the concept of commercial vehicles is becoming a tourist vehicle that can deliver passengers to travel to enjoy the atmosphere of the city into one of the solutions that can be done to revitalize the rickshaw vehicles.

Research highlights on "transport rickshaw tour as a vehicle" is often performed, including; writings described [1], concerning the important role of a tourist rickshaw pullers relationship with vernacular cultural identity as a city. It proves that the traditional rickshaw transport can still be effectively utilized in today's modern urban systems as transportation tours of the city. The study is very helpful in a region that is already formed its touring systems with very good yet explains the root of the problem is more fundamental. Salim [2], explained the need for the capabilities and insight tours on a rickshaw pullers as the heritage tour guides. Heritage tourism can provide knowledge to tourists about the history of the city and travel so that tourists will be more in-depth in the travel tour. Many of the rickshaw pullers are just as workers due to tool owned belongs to the pedicab entrepreneurs or, as expressed by Kurasaki [3]. This almost happened because the role of a big city company can hire employs a lot of informal workers who want to become rickshaw pullers. The rickshaw pullers generally come from the informal sector which has its limitations. Environmental background and limited education and education of higher profession render no rickshaw pullers is preferred. Generally, the rickshaw pullers came from a poor family originating from rural areas and go looking for a job in the city [4]. In the city of Bandung, which is one of the major cities in Indonesia with a population that is increasing. The city became a center of economic attraction which made the villagers work in the city though informally as a laborer, transport workers, rickshaw pullers and pitchman. Generally, the rickshaw pullers are on a down economy class or included in the categories of the poor. Their inability to manage finances became one of the problems in running his life [5]. Bangladesh rickshaw is also one of the very many vehicles used in transport because it does not pollute the air (pollution) is also relatively cheap. Rickshaw pulling is one of the livelihoods of the bottom in order to meet the needs of his life [6].

Rickshaw is a small category ground vehicles based on passenger capacity. Traditional vehicles there has been in Indonesia since long ago as a vehicle capable of ferrying passengers along the edge of the highway to enter the streets of the small town residents in housing. This kind of vehicle is the result of assimilation between a two-wheeled bike with a wheelbarrow. The result is a three-wheeled vehicle with an existing puller in the rear.

The history of this vehicle is recorded in 1865 in the city of Yokohama in the country of Japan. Concepts and ideas first presented by a man named Jonathan Gooble missionaries currently seeking ways to invite his wife named Eliza Weeks walking the streets to see the beauty of the city of Yokohama but deterred because his wife is lame so it's not able to walk. The incident sparked Jonathan to find ways so that his wife 
can still enjoy the beauty of the city without the need of running. Finally, Jonathan tries combining a bike with a wheelchair given thrust so that it is making the bike has the wheels to three for cantilever passengers can sit to enjoy without the need of pedaling [7].

The development of the rickshaw in Indonesia started in 1930 and has the distinction of reason based on existing writing in a journal written by a journalist with Japan in a column called "Pen to Camera". There is described a development industry and sales of the two-wheeled bicycle in Macassar has decreased. Even a wheelbarrow sorely needed there because Macassar is a port city also became a center of trade in Sulawesi. The bike felt can only take a human individual by not being able to carry goods or charge. Bicycle sales decline felt by bicycle, and a few merchants threatened roll mats. The idea of a merchant named SeikoSan modified the bike and wheelbarrow became a vehicle capable of carrying passengers or goods emerge from the bicycle trader is to back exciting sales [7].

Bandung is a city in rapid development, as well as the economic center of Bandung, also known as the city's history. The development of the city as a city which has some historical artifacts, Bandung also has some buildings of heritage value history. Bandung is located geographically on high so it has the cool temperatures with high humidity levels. Bandung is known for its friendly inhabitants with a heterogeneous society. At the time, Netherlands burned the city of Bandung has a central position as of the Government and the military, as well as resting place because of its geographical location. Because this city has many colonial buildings, grounds, and some fortifications from the former remain two countries occupied the Netherlands and Japan.

The recent development of Bandung became one of the centers of development of art and culture as well as education. Bandung also became a center of trade both domestically and internationally, in particular, the sector of tourism, agriculture, textile and culinary. In an earlier era the City Government does not see the tourist aspect of the heritage as one of the charms of the city, but after the Mayor of Ridwan Kamil, Bandung restyled so that it changes the view of some conditions including the city. Among them are; improving the pedestrian space so that more broadly, bicycle lane, and also revitalize some public spaces. In addition, the existence of special attention on all aspects of the heritage buildings that have historical value for preservation and restoration was done does not change the architectural design of the old building.

\section{A. Infrastructure of Bandung}

The construction of the city of Bandung, more emphasis to the physical improvements that deliver impact to the users of the facilities and infrastructure of the city such as; spacious public rooms, thematic parks, sidewalks, street furniture and street lights. More emphasis on the development of the community attempted to give a sense of happy citizens city natives or migrants and travelers.

\section{B. Improving the means of transportation}

Reform of public vehicles, and the enforcement of city bus which is environmentally good mutual interest put forward a city bus or public transport special school children. Enforcement of tour buses in the city of Bandung to conduct tourism activities in the rounds accompanied by a tour guide of the city known as the bus Bandros. Implementation of special lanes for cyclists and the existence of a rental (shuttle bikes) self-contained bike at some point for citizens who want to use the bike in traveling. Provides sanctions and special rules on a vehicle that was not feasible or unofficially as well as disrupt city traffic at some point crowd the city, such as; City freight carriage (buggy), and tricycles.

\section{Heritage Buildings in Bandung}

At some point in the city of Bandung, the building is already aged decades and already changed the function to an office or a school that is currently occupied by the city's community for daily activities. The buildings still largely maintained preserved because it performed maintenance and also reconstruction with without damaging the authenticity of the architecture of the building. The peculiarities of building in Bandung is having an art deco style characterizes the building in his day.

The buildings still exist and remain intact, such as satay, Cathedral Santo Petrus, Bethel Church, Merdeka building, the Savoy Homman, Siliwangi regional military home base as a building and education center, military defense in the way Java to Sumatra, as well as Road buildings or houses of historical figures. In addition to building the city of Bandung also has several parks into the lungs of the city as well as several sports arena that is still actively used and the been done to revitalize a sport that is more modern. Among them is a sports facility in Saparua at Saparua Street and Gazebo located on the front of the government office is Satay building.

\section{The pedicab and Problems}

Tricycles generally have a fairly complex problem, since such vehicles do not have a binding rule or regulation that is clear. In addition to the traditional nature of these vehicles because the course has many flaws and limitations compared to today's modern public transportation. Inability in adapting to the situation and the current state makes this vehicle is exposed to survive and would be abandoned by passengers. In addition to the amount which decreases there are several factors that make this vehicle becomes problematic because of the negative impact on the state of the environment especially in Bandung, including; Tricycles are often a hindrance in the way of this because is too slow cannot increase the speed of motor vehicles, became traffic in Bandung. Tricycles sometimes proceed against the direction of traffic so as to make motorists more distracted and cause traffic. There are not special place cycle rickshaws which consequently termination could do places for vehicle stops. This resulted in the banned of vehicle traffic in the city of Bandung.

A lot of vehicles that pedicab that less maintenance, so that performance looks old and unattractive at a condition of the vehicle. This makes the appearance of rickshaw far from unique even became one of the pollutions that can aggravate the aesthetics of Bandung city. The absence of regeneration on the profession of rickshaw drivers so that the drivers of these vehicles are typically are the ones who are already elderly who should have entered retirement. There is no of a rickshaw repair type renewal mechanism and old system working well in the utilization of technology or regulatory aim in favor of the rickshaw drivers. 


\section{METHODS}

The pedicab is a traditional vehicle still favored by a society of Bandung city. Aside from its shape, the rickshaw is a vehicle that is pollution-free. The emotional thing that is extremely strong pedicab vehicle because almost all elements of people never feel how to be both the pedicab passenger, childhood until adulthood. As the development of modern transport vehicles is increasingly unproductive and likely to become bullies in the flow of vehicle traffic in the city.

This research is descriptive analyses of the problem based on the values in each of the variables that are associated with the problem. This research took some samples by spreading the questionnaires from respondents to the rickshaw pullers totaling 100 sheets but returned 94 pieces. This research also requires the views of customers and users of tricycles from the communities that spread 150 sheet questionnaire and return 123 sheet questionnaire.

\section{RESULT DISCUSSION}

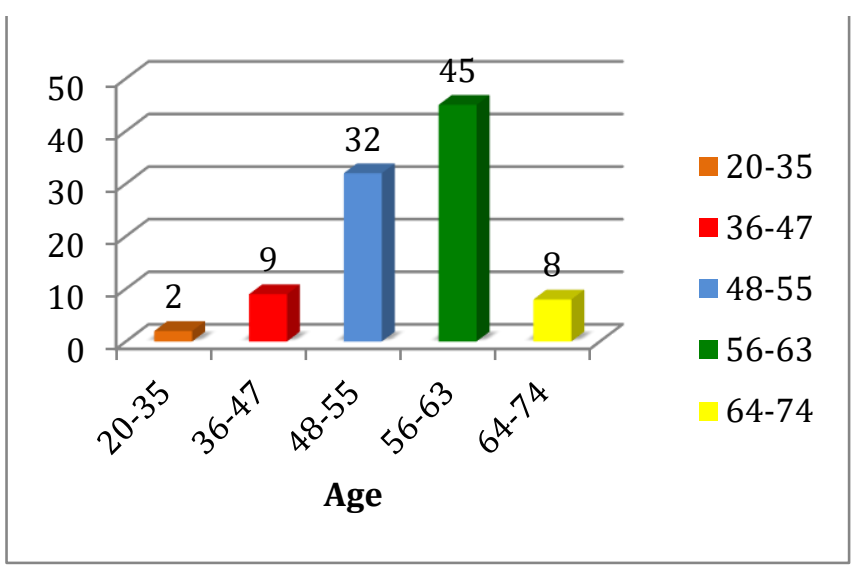

Figure 1. Chart Age Rickshaw Pullers in Bandung

The age of the rickshaw pullers are currently dominated by men with the age range 56-63 years, generally, they have already undergone work as rickshaw pullers for more than 20 years. The profession became the only livelihood needs for his life. Another age range who also dominate is the age of $48-55$ years, this job is done by them because of the difficulty of finding land a job, other informal jobs are generally made as a sideline. An age range of productive age was $36-47$ so that generally work only as a sideline void of time of waiting on idle. A troubled age range was 64-74 because of the rickshaw pullers have very old so his physical health conditions are extremely vulnerable. The last is the age range of young productive i.e. 20-35 done because had to become rickshaw pullers for his family.

From the above data can be found that the vast majority of the rickshaw pullers culprit is a society that has a vulnerable age that is no longer productive i.e. 56-63 years. It was the age of retirement or break stage for human beings in doing work, let alone a job that requires a lot of physical strength. It would certainly be one of the problems that must look for the best solution.

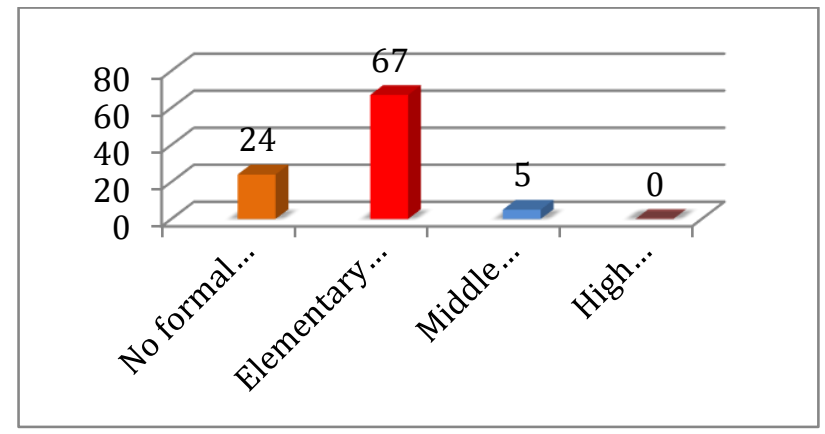

Figure 2. Background Education of Rickshaw pullers

Education is one of the factors that affect the livelihood of the person. In a survey conducted on the rickshaw pullers apparently found most of the level of education that is owned by rickshaw pullers was not successfully completed basic education about 67 people. While entirely who never attended is 24 people. The highest education is the opportunity to get in on the first level of secondary education.

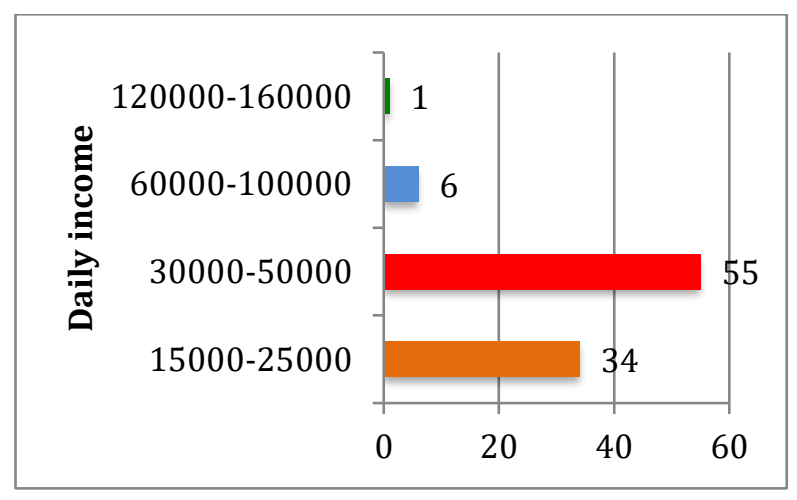

Figure 3. Daily Earnings Chart Rickshaw

The level of living which is owned by rickshaw pullers as the work of the informal is generally low. Living the average received by most of the rickshaw pullers per day about 55 respondents answered at the range of Rp. 30,000-Rp. 50.000,/days, it is at the moment a State conducive, but lately circumstances tend to deteriorate, so that does not cover possible income earned less than expected. The lowest income is at the range Rp. 15,000-Rp. 25.000,-/days, which is the lowest income earned by a rickshaw pullers 34 obtained by the respondent. While the high and highest income between Rp 60,000,-until Rp. 100.000,-/days and Rp. 120,000 ,-until $\mathrm{Rp} 160,000,-/$ days is the income earned by some illegal from rickshaw pullers who happened to everlastingly be available many the role requires a rickshaw as a medium of transportation.

Besides earning some income turns rickshaw pullers was given to owners of rickshaws who rent their vehicles. Generally to the owner of rickshaws has been set a day between $\mathrm{Rp} 15,000$ to $\mathrm{Rp}$. 40,000 depending upon the agreement of the beginning of the contract become Ordinances. 


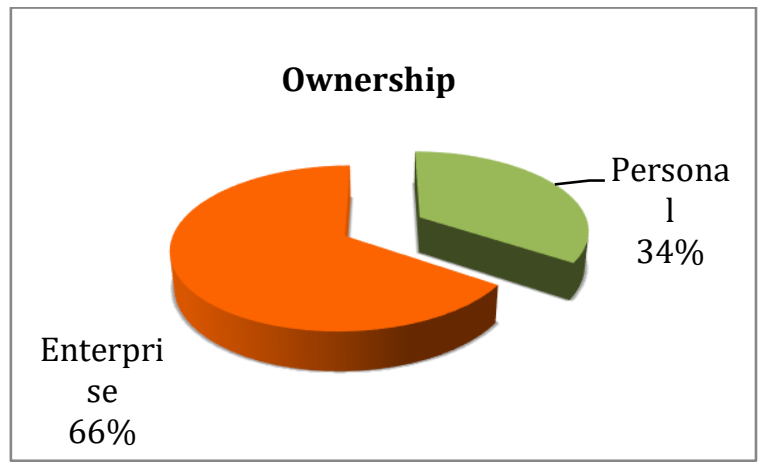

Figure 4. Ownership of rickshaw

Ownership of a rickshaw ride turns out to be as much as $66 \%$ controlled by the rickshaw transport entrepreneurs daily receive the workers ' rent of rickshaws. The remaining 34\% owned by the rickshaw pullers who have purchased and became the private property of the rickshaw pullers.

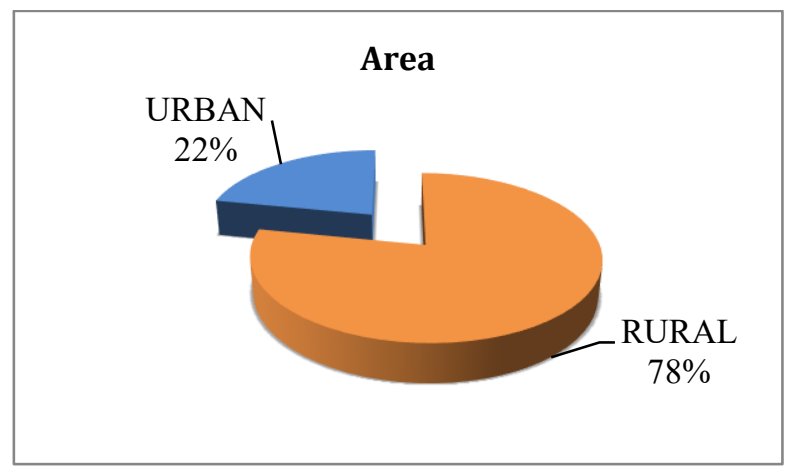

Figure 5. Original Area

Other things found in the rickshaw pullers are in fact there is a guy who comes from out of town or comes from the suburbs and the majority come from the countryside. They find jobs as laborers carried as a land of jobs in the city. As much as $78 \%$ of rickshaw pullers originate from villages and $22 \%$ for a long time been domiciled in the city as residents who settled in the city. This data shows about the rickshaw pullers are currently still operating as rickshaw pullers in Bandung. They operate at different points of the town became the center of the crowd society of the city and still allow for achieved by the rickshaw pullers. Generally, there is a spring in markets, schools, and other crowded.

In Bandung, there is approximately 250 active pedicab operation. There are many rickshaws at a big market who became the center of a crowd of whom reside on the Otto Iskandardinata street in Bandung there are 40-50 more scattered around the outskirts of the Rickshaw and every intersection. On the Pasirkoja streets, there are also many rickshaws because there is some point crowd including schools and traditional markets more or less there is a number of 35-45 rickshaw puller. Rickshaws are also widely available on the people residential because there are several modern malls is also the square which is a public space provided by the Government to be the heart of the bustling city. It is estimated there were 60-70 rickshaws exist around Asia Afrika Street and Cibadak street.

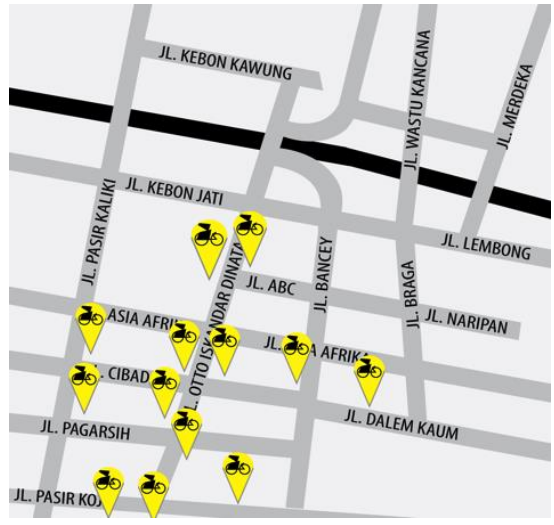

Figure 6. Point of Rickshaws pull on centre of Bandung city

A few other points there are scattered in several roads in Bandung generally exist residential or public or private housing estate located by the entrance street. The discussion expanded to know the element of sensation is emotionally perceived by passenger tricycles while traveling by rickshaws. Done gathering questionnaires for some 123 customers who have been and have become accustomed to using the rickshaws as daily transportation.

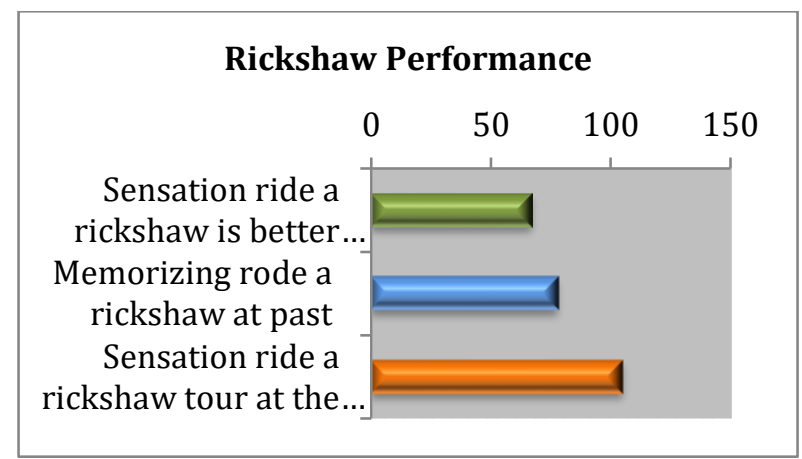

Figure 7. Rickshaw Performance

The reaction of the passengers during the trip when riding tricycles generally feel a sensation of a drive is different. Rickshaw gives the sensation of a more keep the fresh air from pollution while driving there are 67 respondents agreed. Rickshaws also became a driving experience in the past making a nostalgic memory for some passengers. As many as 78 respondents approve of pedicab experience evokes the memorabilia. For most is to feel a sensation of riding a rickshaw in the middle of the city, as many as 105 respondents agreed.

In addition, there is a perceived thing distracting while driving a pedicab among them; a). speed rickshaw outrageously slow makes the disturbing rate of an existing vehicle behind him especially motor vehicles by as much as 34 respondents, b). feel less comfortable when climbing and descending of the pedicab as much as 44 respondents, c) feel insecure when encountered an incline, as many as 62 respondents $d$ ). the large number of rickshaws that violates traffic/against the flow by as much as 57 respondents e). worry crash with motor vehicles by as much as 33 respondents. 


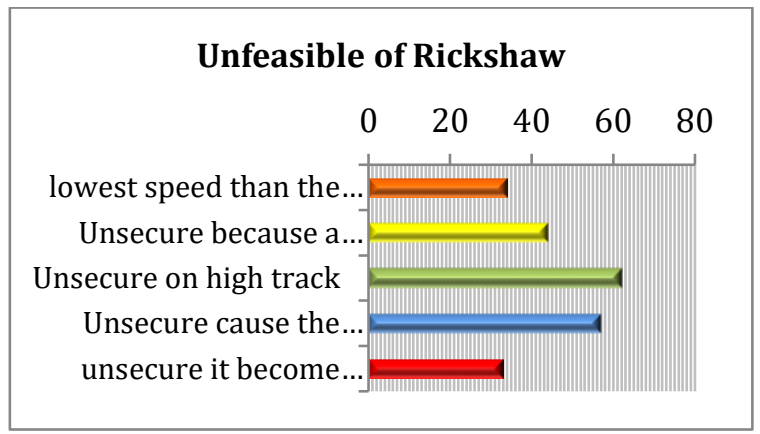

Figure 8. Things that made passenger fill worry

Observe the visual appearance of the pedicab is currently showing the technical aspects contained on this vehicle. There are some aspects that are common among them complained of elevators; a). Physical appearance (Physiology) vehicle that shows many are not preserved, as many as 78 respondents approve of it. b). The tariff or cost though not a physical thing but the clarity with regard to the value of a service, as many as 50 respondents approve of because there is no definite rate indicated in the vehicle (oral only). c). The outward appearance of rickshaw pullers is not feasible, such as towing a shabby and unfriendly, as many as 66 respondents agreeing. d). The Chair part passenger feels cramped especially for more than two passengers, a total of 56 respondents agreeing.

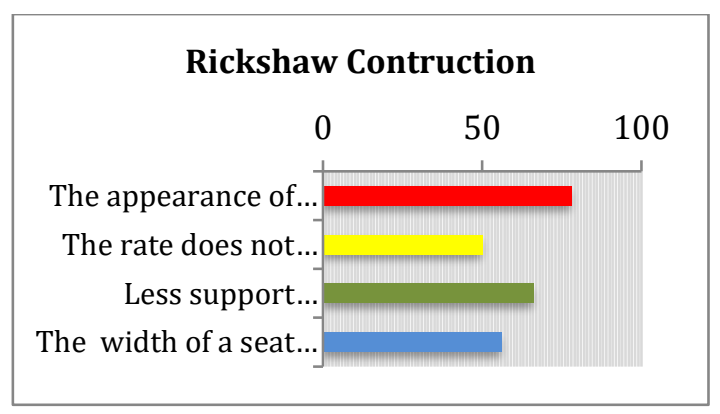

Figure 9. The Rickshaw Contructions

Looking above results surely needed support from all the parties will be able to influence a pedicab advocates revitalization of tourism. The Government should play an active role in relocating the rickshaws without causing new problems. The influx of city tours in the program the Government will make socialization towards historic places in the city to be more aware. Pedicab sightseeing tours of the city will give you feel of a more authentic past against giving a sensation of nice trace on the history of the city.

Such as those results along with other users is the same as in becak expressed by Salim [25], the tour using the rickshaw has its own uniqueness that can not be replaced in addition also a rickshaw It is the vehicle that is sustainable and carbonfree making tricycles have important values at this time. City tour visiting some places and buildings that have historical value would certainly be an experience is valuable for individuals who experience it.
TABLE 1. RICKSHAW CITY TOUR IMPLEMENTATION

\begin{tabular}{|c|c|c|}
\hline $\begin{array}{l}\text { Information } \\
\text { Route }\end{array}$ & $\begin{array}{l}\text { Transportation } \\
\text { modified }\end{array}$ & Regulation \\
\hline $\begin{array}{l}\text { Route I } \\
\text { Balaikota } \\
\text { Merdeka street - } \\
\text { Aceh street - } \\
\text { Saparua street - } \\
\text { Sumbawa street - } \\
\text { Belitung street - } \\
\text { Aceh street - } \\
\text { Merdeka street } \\
\text { Route II } \\
\text { Balaikota - } \\
\text { Merdeka street - } \\
\text { Veteran street } \\
\text { Tamblong street, } \\
\text { Asia Afrika street - } \\
\text { Braga street, } \\
\text { Merdeka street. } \\
\text { Route III } \\
\text { Balaikota - } \\
\text { Merdeka street } \\
\text { Aceh street - } \\
\text { Banda steet } \\
\text { Dipenogoro } \\
\text { street-Martadinata } \\
\text { - Merdeka street. } \\
\text { Irma suryani } \\
\text { park, Saritage } \\
\text { Musueum } \\
\text { Saparua park, } \\
\text { Balaikota, } \\
\text { Musieum Bank } \\
\text { Indonesia } \\
\text { Taman } \\
\text { Vanda, Mandala } \\
\text { wangsit Museum, } \\
\text { Katedral santo } \\
\text { petrus centrum, } \\
\text { Then }\end{array}$ & $\begin{array}{l}\text { Pedicab Modified: } \\
\text { - lighter } \\
\text { - More comfortable } \\
\text { - More efficient } \\
\text { - Maintaint } \\
\text { vernacular unique } \\
\text { - posible change to } \\
\text { electic } \\
\text { Rickshaw puller } \\
\text { - professional } \\
\text { - clean \& fragrant } \\
\text { - cultural clothes } \\
\text { - good } \\
\text { communication } \\
\text { - tour guide }\end{array}$ & $\begin{array}{l}\text { Government } \\
\text { Regulation } \\
\text { (Undang- } \\
\text { undang) } \\
\text { (Perwalkot) } \\
\text { Mayor city of } \\
\text { Bandung } \\
\text { Formal } \\
\text { Government } \\
\text { Regulation } \\
\text { - Mark on street } \\
\text { - Rickshaw dock } \\
\text { - Maintainance } \\
\text { place }\end{array}$ \\
\hline
\end{tabular}

\section{CONCLUSION}

As a conclusion of the pedicab is a unique vehicle that has good ability to tour on the city. Despite many improvements need to be made to make the uniqueness of rickshaws became one of the tourist value can be preserved. In addition to developing tourism heritage also maintain or preserve the traditional vehicles of the cultural wealth of vernacular as pedicab Indonesia.

\section{ACKNOWLEDGMENT}

This research is intended to be a consideration to the Government of the city of Bandung in the development and preservation of the cultural heritage of the becak traditional transportation that has potential as a tourist city tours 


\section{REFERENCE}

[1] Zhang, Lijun. Performing Locality and Identity: Rickshaw Driver, Narratives and Tourism'. BNU, Cambridge Journal of China Studi, The Daily Life Research of Urban Status Groups (SKZZB2015032), The Central Universities, PRC, Volume 11, No.1/88, 2015.

[2] Salim, Nurbaidura; Othman, Abdul Ghapar, Mohammed, Badaruddin, "Heritage Awareness Among Tour Operators in Heritage Site; A Case Studi of Rickshaw Pullers in Malaka." Sustainable Tourism Research Cluster and School of Housing, Building, and Planing, Universiti Sains Malaysia, Penang, Malaysia, 3rd ICBER 12-13 March 2012.

[3] Kurosaki, Takashi; Banerji, Asit; Mishra S. N; Mangal, A.K, Unorganized Enterprises and Rural-Urban Migration in India; The Case of the Cycle Rickshaw Sector in Delhi, Hitotsubashi University Repository, Hermes-Ir, July 2012.

[4] Begum, Sharifa and Sen, Binayak, Unsustainable Livelihood, Health Shocks and Urban Chronic Poverty; Rickshaw Puller as a Case Study, Chronic Poverty Research Centre, ISBN Number; 1904049-45-1, Novermber, 2004.

[5] Nandhi, Mani Arul, The Urban Poor and Their Money; A Study of Cycle Rickshaw Pullers in Delhi, Microfinance Researchers Alliance Program University of Delhi, June 2011

[6] Al Baki, Abdullah, Rickshaw Pulling and Change in Life; A Case of Uttara in Dhaka City, Institut of Governance Studies BRAC University, Dhaka, March 2013.

[7] Akbar, Jay. HistoriA. 23 Juni 2010. Geomedia Network. 2 Mei $2017<$ http://historia.id $>$. 